\title{
STIMULI OF COLLABORATION IN PRODUCT DEVELOPMENT: A CASE STUDY IN A PROJECT MANUFACTURING COMPANY
}

\author{
Aki Jääskeläinen, Jussi Heikkilä, Anna Hiidensalo, Otto Thitz \\ Tampere University of Technology, Industrial and Information Management, Finland \\ Corresponding author: \\ Aki Jääskeläinen \\ Tampere University of Technology \\ Industrial and Information Management \\ Korkeakoulunkatu 8, P.O. Box 541, FI-33101 Tampere, Finland \\ phone: +35850 3261113 \\ e-mail: aki.jaaskelainen@tut.fi
}

Received: 5 July 2017

Accepted: 8 November 2017

\begin{abstract}
There is already a wide acceptance on the importance of involving supplier and customer companies in product development. Decent understanding prevails on the relationshiporiented approach to product development including various collaboration forms. However, there is less research on the factors explaining the decision of attending to joint product development. In addition, less studies have examined the integrated role of both suppliers and customers in product development initiatives. This study searches answers to the following research questions: 1 . What is the role of different actors in product development initiatives? 2. What factors motivate suppliers and customers to participate in product development? The research is carried out as an in-depth qualitative single case study in a large project manufacturing company. It takes the perspective of a focal company striving for product improvements. The first part of the empirical study consists of 15 semi-structured interviews. The second part includes two discursive workshops and builds upon the results of the interviews. This study contributes to the existing research by explaining the challenges and conditions facilitating joint product development with supplier and purchaser companies. The results highlight the role of customers in improving the effectiveness of product development. As a practical contribution, the paper reports the application of workshop method as a facilitator of collaboration between supplier, purchaser (focal company) and customer companies.
\end{abstract}

KEYWORDS

collaboration, supplier involvement, customer involvement, product development, purchasing, supply management, case study.

\section{Introduction}

The importance of collaboration in product development has been acknowledged for a long time. Development of complex products often requires collaboration crossing organizational boundaries enabling the use of complementary knowledge and resources $[1,2]$. There is already a lot of literature on involving both suppliers [e.g. 3, 4] and customers [e.g. $1,5]$ to product development. The literature of product development includes many factors promoting inter-organizational collaboration [6]. The benefits of involving suppliers to product development include leveraging supplier knowledge to reduce costs and lead times of product development [7], getting better access to supplier technology [8], and increased innovation outcomes due to resource pooling and complementary capabilities [9]. In addition, customer involvement may have a positive impact on product success [10], understanding of customer needs [5] and competitor moves [11]; and generation of new ideas [12].

The level and degree of supplier innovation in terms of product development is one of the main competitive priorities in supplier selection [13]. Earlier research has often considered how external part- 
ners for joint product development should be chosen [2]. Also the relationship-oriented approach to product development has gained increasing attention in the literature with the interest in the impact of relationship characteristics and relationship management on product development [e.g. 14, 15]. However, there is less research on factors explaining whether customer and supplier involvement in product development will take place or not $[1,11]$. This is essential especially in the opening stages of product development often regarded as essential for the product development success, due to decisions regarding design teams and impacts on overall time and costs [16]. In the early phases of product development, the time demands for customers or suppliers can be greater [17], which potentially decreases the motivation for participating in the product development of a focal company typically owning the product rights.

An aspect of novelty [cf. 18, 19] in this study relates to its case context representing make-toorder industry with JIT (just-in-time) supplies [19, 20] consisting of tailored project offerings to customers. In this context, flexibility and responsiveness of operations and supplies [19], integration of design and manufacturing [21], and inter-organizational collaboration [22, 23] have been highlighted. A customer is an important actor [19, 21] affecting the whole supply chain. However, it has been found that engineering-oriented mindset highlighting sophisticated techniques instead of customer preferences is still perceivable in many companies providing customized offerings [24].

This study highlights the increased effectiveness of product development as a result of collaboration across several companies; the focal company as the owner of product rights, its suppliers and customers. It aims to understand the drivers of interorganizational collaboration in the opening stages of product development projects. More specifically, the study searches answers to the following research questions:

RQ1. What is the role of different actors in product development initiatives?

RQ2. What factors motivate suppliers and customers to participate in product development?

The research applies an in-depth qualitative case study approach in a large project manufacturing company. As its main result, the paper highlights the importance of customer company in product development involved by the focal company and its suppliers. It also gives insights on product development in the collaboration between supplier, purchaser and customer. The main unit of analysis in this study is a focal company owning the product rights and aiming at development of its products with the facilitation of its suppliers and customer company. Furthermore, the role of the focal company in facilitating collaboration between suppliers and customer companies is examined.

The literature review of the paper is divided into two main streams in the literature [cf. 2]: supplier involvement and customer involvement in product development. The paper continues by presenting the methodology used in the empirical part. The empirical results are examined in line with the posed research questions. Finally, the discussion and concluding remarks are presented.

\section{Literature review}

\section{Supplier integration in product development}

Earlier research suggests that suppliers are key stakeholders in product development, although empirical evidence has not always been unambiguous [25]. Many potential benefits such as access to new technologies and novel capabilities have been identified in utilizing suppliers in product development $[2,26]$. Lau [27] remarks that as product components or modules are outsourced to suppliers, supplier involvement becomes more significant. Song and Di Benedetto [28] add that when a highly innovative product is developed the manufacturer seeks information from suppliers in order to shorten product development time and to reduce the costly design changes. However, it has also been found that the positive outcomes of supplier involvement in product development are difficult to achieve [29, 30]. As an example, a supplier might not be acquainted with the peculiarities of the developer company's operations processes and the particular technical requirements.

A starting point for inter-organizational collaboration in product development is a supplier's willingness to participate. According to Schiele [31], all suppliers are not willing to cooperate with buying companies, which is why it becomes important to achieve preferred status among key suppliers. There can be several barriers to product development collaboration such as the resistance towards information exchange in fear of knowledge spillovers [32]. A customer may fear that suppliers might reveal something intentionally or unintentionally to customer's competitors while a supplier might fear inequitable treatment from the customer's side [8]. Ragatz et al. [8] further argue that these barriers can be overcome by structuring long-term relationships and by proper asset allocation. 
Rowley et al. [33] indicate that an inherent relationship with customers motivates a supplier to use its own knowledge to develop innovations that meet the focal company's needs. Also Ellis et al. [34] found that preferred customer status is positively associated with the willingness of suppliers to share new technology with the focal company. The results of the study by Wagner and Bode [35] highlight that suppliers are more likely to share process innovations and are less hesitant to share product innovations with customers when the relationship-specific investments go along with long-term and strong purchasersupplier collaboration. Koufteros et al. [36] argue that to achieve a supplier's trust, the focal company can use supply base rationalization strategies to reduce the number of suppliers and to give a larger volume to suppliers it chooses to closer collaboration.

Wynstra et al. [29] defined conditions for successful supplier involvement: 1) identifying specific processes and emission that need to be carried out, to support at the integration of product development and purchasing; 2) forming an organization that embraces the execution of such tasks; 3) having employees which have the right commercial, social and technical skills. Also the promise of shared value can motivate suppliers to product development collaboration. Smals and Smits [37] identify three ways how customer companies can offer value to their suppliers: 1) financial payment for sales and product development, 2) increasing technological knowledge, and 3) reputational benefits associated to doing business with well-known firm.

Traditionally, supplier innovations have been pulled by the focal company, while the need for independently pushed innovations has been widely acknowledged [35]. Lakemond et al. [38] present three general types of organizing supplier involvement in product development which combine these two ways to supplier innovations. The first is an integrated way of working, where information is changed on a continual basis. The second is an ad hoc approach; a supplier is contacted when a problem occurs. The third is based on a more independent role of supplier.

The typology of Lakemond et al. [38] is similar to typology presented by Petersen et al. [39] who divided supplier involvement in product development into three different types. The first type is black-box development, in which a supplier's role is the most comprehensive. In black-box development, a supplier takes responsibility for developing the component or subassembly according a customer's requirements [2]. The second type of supplier involvement in product development is gray-box development where a supplier and a customer work alongside each oth- er [36]. Koufteros et al. [36] continue that graybox development allows the integration of supplier's processes in the design. The third form of collaboration is white-box development which is customerdriven and where the supplier's role is limited. In white-box development, the supplier contributes only by commenting on the customer's design [2]. In this study, the desire of the focal company is to find a way of collaborating in a continual basis meaning both pushed and pulled ideas for product development and the gray-box approach.

\section{Customer integration in product development}

A challenge in utilizing the innovation potential of suppliers is the lack of sufficient knowledge about customer company needs limiting the understanding of potential areas for innovating [40]. Hence, a focal company should also consider customer company in improving its product development. Collaboration with customers has become a major component of the development efforts of many companies [41] which increasingly see customers as a source of knowledge. Companies learn from their customers and new technologies push forward open forms of innovation and cooperation with customers [42]. Product development can benefit from in-depth understanding of customers, their situation and needs [5] supporting the achievement of ideal costs and time in production and reducing uncertainties related to environment and customer demand [16].

Customer involvement in product development requires active interaction with customers [11]. This interaction may take forms such as small group exercises and prototype testing [12], customer involvement in product development teams [5] as well as more traditional forms such as opinion boxes or customer interviews [16]. Lead user method has been presented as a means to specifically facilitate early insights into customer needs and solutions for satisfying such needs $[24,41]$.

While it is often beneficial to involve customers in product development of a supplier company, participation of customers to product development is not self-evident and customer companies should carefully consider the advantages and disadvantages involved. Required costs can be substantial, particularly with greater involvement [17]. Many factors such as mutual commitment, mutual trust, mutual adaptations and mutual relationship management $[11,14]$ have been found to have a positive effect on the involvement of customers in product development. Customers are motivated to be involved in product development specifically when price reductions, exclusive rights to the products, extra service and war- 
ranties are sought for [17]. Other factors motivating customers include financial compensations, expectations of better offerings and greater opportunity for choice [41].

In turn, strong brand of a supplier company may hamper the motivation of customers to involve in product development since customers may feel that they voluntarily participate in activities aiming at increasing the value of the supplier's brand. Also an intense competitor focus may demotivate customers to involve in product development due to perceived larger emphasis on competitors than on customers [11].

Customer involvement can occur in different phases of product development $[5,12]$ such as specification, concept development and prototyping [12]. The depth of customer involvement may vary in different phases. Nambisan [43] points out that customers can be involved not only in providing new ideas but also in co-creating them with suppliers, in testing ?nished products, providing product support, and continuous improvement. According to Kaulio [12] the involvement of customer in product development can generally take the following three forms:

1) "Design for" is an approach where products are designed on behalf of customers based on gathered ideas and customer needs.

2) "Design with", where in addition to the abovementioned, customers can react to different proposed design solutions.

3) "Design by" refers to an approach where customers are actively involved and participate in the product design.

In this study, the approach where products are designed with customers is highlighted. In this phase product concept and solutions are jointly developed by customer and supplier companies. The collaboration is characterized by on-going discussion between customer and supplier during the product development process [12]. The emphasis of this study is especially in the initial stages of starting joint development efforts requiring initiatives and new ideas to be implemented. The collaborative design usually happens in the initial phases of product development [41].

\section{Summary of the literature}

The reviewed literature points out that increasing attention has been paid to involving both suppliers and customers to product development. Suppliers are the most notable and acknowledged companion in product development efforts whereas customer involvement has more recently gained more attention. Despite the indisputable benefits involved, there are also risks and sacrifices involved concerning each of the participating actors. Therefore, it is important to study in-depth the role of each actor into joint product development. Many earlier studies stress the perspective of focal company while there are less studies simultaneously assessing several counterparts in the product development [37]. In addition, many of the earlier studies have studied either supplier or customer involvement as separate perspectives to the issue. However, it has been found that the involvement of supplier and customer is highly integrated [27]. When a company develops supplier involvement, it authenticates a good foundation for customer participation and vice versa. The empirical part of this study intends to shed more light on product development collaboration involving suppliers, purchaser and customer companies through an embedded single case approach.

\section{Methodology}

The study was carried out as a qualitative single case study reflecting a critical case fitting to the posed research questions [44]. The embedded case study highlights the perspective of the case company (later focal company) and its relationships between two suppliers and one of its customers. The focal company is a global project manufacturing company which has around 12,000 employees. The purchasing function of the focal company coordinates the collaboration with suppliers in the focal company and was chosen as a facilitator of a program (later development program) aiming at improving both crossfunctional and inter-organizational collaboration in product development. In the focal company, the focus is specifically on redesign activities which are an important part of product development [45].

Four companies were involved in the empirical part of this study. The followings notation for the companies is used: focal company, Customer, Supplier A and Supplier B. Customer is a Finnish process industry company that operates in international markets. The offerings consist mainly of physical products that are sold further to other companies or directly to consumers. Customer has also notable research and development operations and aim for radical technology innovations in its industry. Supplier A is a global technology provider company. The offerings consist of products and technologies related to rotating equipment. Supplier B is a global company in the engineering industry. It provides tailored power industry-specific solutions.

The purchasing of the focal company handles global operations and has an extensive supply chain. 
The total spend of direct purchases is around EUR 1-2 billion annually which is purchased from thousands of suppliers in over 50 countries. Numerical details regarding focal company's supplier base and purchasing are provided in Table 1.

Table 1

Key figures of purchasing and suppliers of the focal company.

\begin{tabular}{l|c}
\hline $\begin{array}{l}\text { Proportion of the purcha- } \\
\text { sing spend of all costs }\end{array}$ & $65 \%$ \\
\hline Supplier count & 10,000 \\
\hline $\begin{array}{l}\text { Share of purchased mate- } \\
\text { rials and services }\end{array}$ & $80 \%$ materials, $20 \%$ services \\
\hline
\end{tabular}

Figure 1 presents the units of analysis in this study. The study is carried out from the perspective of the focal company with the emphasis in development of its products. The first unit of analysis relates to the involvement of suppliers to the product development of the focal company. Second unit of analysis takes the perspective of involving customer to the product development in the focal company. Customer is defined as an immediate B-to-B customer of the focal company. The third analysis unit examines the connection bypassing focal company, i.e. product development relationship between supplier and customer as well as customer and supplier.

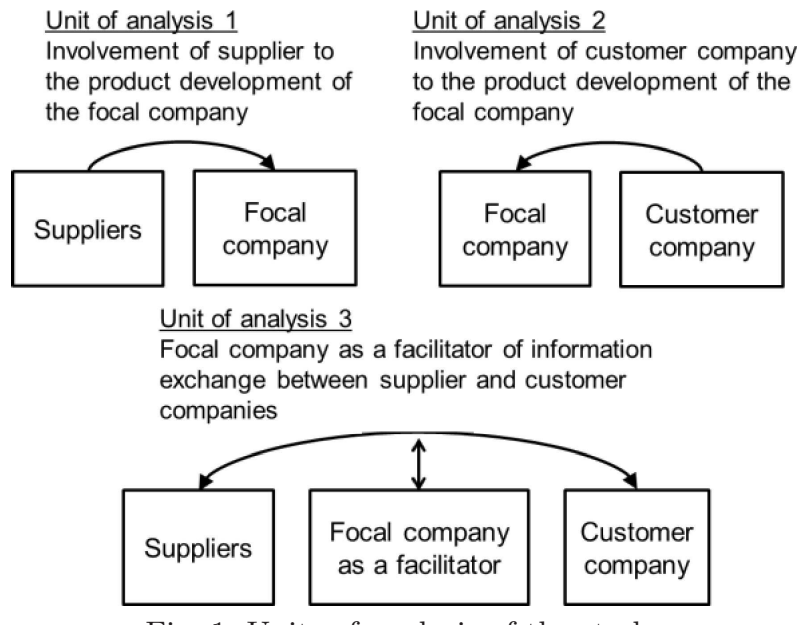

Fig. 1. Units of analysis of the study.

The applied research methods and their connections to the research questions and units of analysis are presented in Table 2. This study utilizes both interviews and discursive workshops as a source of empirical data. The leaders of the development program of the focal company proposed candidate interviewees representing purchasing function (including supply chain) and two other functions regularly involved in product development, namely product development and manufacturing. Hence, the choice of interviewees followed the logic of theoretical sampling since the choice was driven by the anticipated high level of knowledge in light of the research questions [46]. The final choice of 15 informants was made jointly between company representatives and the researchers with the emphasis on interviewees both on the mid-level (later referred to as managers) and toplevel (later referred to as directors).

The 15 semi-structured interviews studied initiatives to product development and collaboration with suppliers in product development. Description of the interview themes is presented in Table 3. The interviews were conducted in May and June 2015. The duration of interviews was from 40 to 90 minutes. The interviews were audio-recorded and transcribed to an electrical document.

After the analysis of interview study findings, two informal meetings were organized with two representatives (a purchasing director and a development program manager) of the focal company. Since the significance of inter-organizational collaboration in product development was a key observation in the interview study, it was deemed important that a workshop attended by two suppliers, focal company and its customer company is organized. A workshop with complementing personnel roles and organizational parties were seen as a valuable way to acquire in-depth information of relationships. According to Van de Ven and Delbecq [47], interactive group discussions often create more valuable information than their best member alone. Also Kim and Ahn [48] present that increasing complexity of the contemporary environments makes it less possible for a single decision maker to consider all aspects of the problem. This study utilized the interactive group technique by applying semi-structured workshops with pre-defined discussion topics in line with the research questions.

Two workshops were organized. Most of the interviewees also participated in the workshops. The first workshop was organized in October 2015 and it lasted for three hours. In the first workshop, there were six representatives from the focal company, two representatives from Customer and one representative from both Supplier A and B. There were also four representatives from a research group including three of the authors, who observed the discussions and facilitated the workshop events. The first workshop consisted of group conversations where the participants were divided into three smaller groups. Additionally, one research group member participated in each small group to document the discussion. At the end of each theme, all participants discussed the perceptions and different solutions together. 
Table 2

Research methods and informants.

\begin{tabular}{|c|c|c|c|c|}
\hline Research question & More specific theme & Unit of analysis & Research method & Informants \\
\hline RQ1 & $\begin{array}{l}\text { Role of different actors in } \\
\text { product development initia- } \\
\text { tives }\end{array}$ & 1 and 2 & \multirow{2}{*}{ Interview study } & \multirow{2}{*}{$\begin{array}{l}\text { Focal company: } \\
1 \text { supply chain director } \\
4 \text { purchasing managers } \\
2 \text { purchasing category managers } \\
2 \text { product development directors (one } \\
\text { of engineering, one of technology) } \\
4 \text { product development managers } \\
2 \text { production directors (of two differ- } \\
\text { ent business lines) }\end{array}$} \\
\hline RQ2 & $\begin{array}{l}\text { Factors perceived to moti- } \\
\text { vate suppliers to product } \\
\text { development }\end{array}$ & 1 & & \\
\hline RQ1 & $\begin{array}{l}\text { Initiation of product de- } \\
\text { velopment between supplier } \\
\text { and customer company }\end{array}$ & 3 & \multirow[b]{2}{*}{ Workshop 1} & \multirow{2}{*}{$\begin{array}{l}\text { Focal company: } \\
1 \text { purchasing director } \\
1 \text { purchasing program manager } \\
1 \text { purchasing manager } \\
2 \text { purchasing category managers } \\
1 \text { product development manager } \\
\text { Supplier A: } \\
1 \text { strategic account manager } \\
\text { Supplier B: } \\
1 \text { product director } \\
\text { Customer company: } \\
1 \text { purchasing category manager } \\
1 \text { maintenance manager }\end{array}$} \\
\hline RQ2 & $\begin{array}{l}\text { Factors motivating each ac- } \\
\text { tors to joint product devel- } \\
\text { opment }\end{array}$ & 1 and 2 & & \\
\hline RQ1 & $\begin{array}{l}\text { Implications of Workshop } 1 \\
\text { findings (information flows, } \\
\text { see Fig. 2) }\end{array}$ & 3 & \multirow[b]{2}{*}{ Workshop 2} & \multirow{2}{*}{$\begin{array}{l}\text { Focal company: } \\
1 \text { purchasing director } \\
1 \text { purchasing program manager } \\
1 \text { purchasing manager } \\
3 \text { purchasing category managers } \\
2 \text { product development managers }\end{array}$} \\
\hline RQ2 & $\begin{array}{l}\text { Review and confirmation of } \\
\text { Workshop } 1 \text { results }\end{array}$ & 1,2, and 3 & & \\
\hline
\end{tabular}

Table 3

Interview themes.

\begin{tabular}{l}
\hline Background information of the respondent \\
\hline Initiation to product development \\
- external and internal sources for product development ideas \\
- forms of product development initiatives \\
\hline Collaboration with suppliers in product development \\
- current challenges in committing suppliers to product development \\
- factors motivating suppliers and the focal company to joint objectives \\
- collaboration forms with suppliers
\end{tabular}

All eight participants of the second workshop were from the focal company. Additionally, there were three representatives from research group (two of the authors) documenting the event. The second workshop was organized in December 2015 and it lasted three hours. Memos of the workshops were written down to an electrical document. The second workshop elaborated the results of the workshop one. In the beginning of the workshop two, the gathered data from the workshop one were presented to the focal company with a slide show in order to get feedback and to ensure the correctness of the data. The more specific topic of the workshop was to investigate the information flows between the studied companies, possibly bypassing the focal company.

The analysis of the results of both interview and workshops was carried out inductively according to the set research questions. The analysis was carried out by two of the authors first separately and then by comparing and combining the analysis. In addition, the validity of results as a reflection of true observations in practice was reviewed by the representatives of the focal company.

\section{Empirical results}

\section{Overall status of inter-organizational product development}

A product development director described the transformation in the product development activities of the focal company. For 10-20 years ago the company developed and manufactured many product components in-house. There was an instant internal 
contact between product development and manufacturing which facilitated specification changes during the project deliveries. However, the search for costeffectiveness led the company to outsource the manufacturing of many parts of the products. This created challenges in handling changes in product designs caused by customer demands.

Most of the purchasing employees regarded that the early involvement of suppliers to product development projects is valuable especially when the focus of the development project is not merely in the own technology of the focal company and there is a need for an extrinsic resource. The focal company had encouraged suppliers to bring out divergent development ideas and this was also a part of its purchasing and supply chain strategy. Especially partner suppliers were invited to be a part of product development projects. Also the representative of Supplier A commented that the focal company was increasingly active in the early contacting regarding product development. However, the initiation of product development ideas was seen as a major challenge by the interviewees of the focal company. A purchasing manager explains:

"The challenge is that we have not managed to establish a reliable process for delivering supplier development ideas through our organization and ascertaining that feedback is provided to suppliers."

The focal company also acknowledged the importance of communicating with customer company in product development but this collaboration was only gradually receiving more attention. Some interviewees utilized a term "fit for purpose" meaning that production and product specifications need to be scaled by customer needs. It was mentioned that customer needs are often culturally bounded.
While in some areas customers appreciate long product life-cycles and usability of machines, in other areas customers are mostly interested in payment periods and prices of the offered machinery. Increasingly, it was deemed important that some features of products which are not valued by customers can be stripped off.

According to Customer represented in workshop 1, there was still room for improvement in the focal company's understanding of customer needs. Also the representatives of suppliers commented that the focal company pays perhaps too much attention to the prices of its products leaving maintenance costs for the customer with less attention. Customer stated that its improvement ideas regarding focal company's products did not seem to lead to concrete changes in the offerings. This was a contrasting viewpoint to the perceptions during the interviews of the focal company reflecting the lack of supplier or customer ideas to product development.

\section{Initiators to joint product development efforts}

According to the interviewees, the initiation to product development can come from three directions: from the employees of the focal company, and its suppliers and customers (see Table 4). When considering the focal company itself, a purchasing category manager presented the next three options for the sources of initiatives:

"First, the product-specific team, because they have the most detailed information on the products. Second, the top management giving a signal to improve price competitiveness. Third, a [product] development team which has already understanding on a new manufacturing method or materials which could be benchmarked and applied more widely."

Table 4

Initiators of product development efforts.

Perspective to the research question (RQ1)

\begin{tabular}{|c|c|c|}
\hline \multicolumn{3}{|c|}{ Perspective to the research question (RQ1) } \\
\hline Supplier & Focal company & Customer \\
\hline $\begin{array}{l}\text { - Ideas on unnecessary elements in } \\
\text { product specifications presented in reg- } \\
\text { ular supplier-purchaser meetings } \\
\text { - Direct contact with customers was } \\
\text { desired }\end{array}$ & $\begin{array}{l}\text { Initiators } \\
\text { - product-specific team } \\
\text { - top management } \\
\text { - development team with understand- } \\
\text { ing of a new manufacturing method } \\
\text { Contact with suppliers } \\
\text { - transferring the messages of cus- } \\
\text { tomer companis } \\
\text { - supplier meetings for identifying in- } \\
\text { correct product designs } \\
\text { Customer analysis results } \\
\text { - past and expected needs }\end{array}$ & $\begin{array}{l}\text { - Signaling on cost-competitiveness } \\
\text { both directly and indirectly (lost bids) }\end{array}$ \\
\hline
\end{tabular}


When looking at the sources of initiatives outside the focal company, one of the main initiators was reportedly customer companies. According to several interviewees, customers are the most significant impulse to start product development. A purchasing manager stated that customer company requirements have effects upstream in the supply chain and they may require redesign of suppliers' existing products or components. According to a product development director, customer companies create a cost pressure for initiating product development projects:

"Customers indicate that you are too high-priced in that area, and we get a good conception that in what area we have challenges compared to the product cost of a competitor. It starts from customers, in other words cost pressures are the practical initiative. [...] We strive to construct a product development project in such a way that there is a customer always involved in it, in order to obtain knowledge on what exactly to develop."

According to a purchasing manager, the initiative of a customer company can also lead to the discussion with suppliers in order to share the problem:

"We can indicate that we do not get sales and you [suppliers] cannot get the business either. So something needs to be figured out together."

Some interviewees also stated that since the focal company was a traditional engineering company there still was a culture where advanced technologies were valued instead of listening to the preferences of customers. However, customer needs from the past and expected needs for the near future where increasingly utilized in the starting point of new product development projects.

The third source for initiatives in product development is suppliers. Suppliers can be active and give their ideas on how the product could be done better or if they have recognized something unnecessary in the product specifications. Sometimes the own product development initiatives of the focal company lead to the need to involve suppliers into the process. A purchasing manager describes the situation:

"We demand from our suppliers that they inform us on the possibly incorrect product designs from the perspective of manufacturing techniques. [...] We work in a close collaboration in order to improve the cost competitiveness of our offerings. We have regular meetings with the supplier two times a year."

The purchasing function of the focal company was widely regarded as the main channel in the communication with suppliers which sometimes involved representatives of product development to the discussion on product changes.
A further area of investigation in this study was whether the initiation to product development could originate from the relationship between suppliers and customer companies. Supplier A considered it important that it could bring its own ideas which could directly benefit the focal company's customer, especially when they have specific knowledge of the customer company's industry. At the present Supplier A's understanding about customers was weak. This comment was mentioned when the quality levels satisfying customer company needs was discussed. Supplier A was keen to know better the customer segments of the focal company. In this discussion the concept of optimal quality was mentioned: provision of quality satisfying customer requirements but not over-quality. Both Supplier A and the focal company emphasized the same demand: there is a need for the development process where the focal company's offerings respond to a customer company's product requirement standards. Also Customer representatives participating in the workshop agreed with Supplier A on the idea of delivering optimal quality for customers.

In workshop 2 the representatives of the focal company deemed it significant to recognize the characteristics of information flows when involving both customer companies and suppliers in product development. There is always a risk of losing confidential information because all these counterparts impel their own interests. Figure 2 presents the desirable model of information exchange from the viewpoint of the focal company.

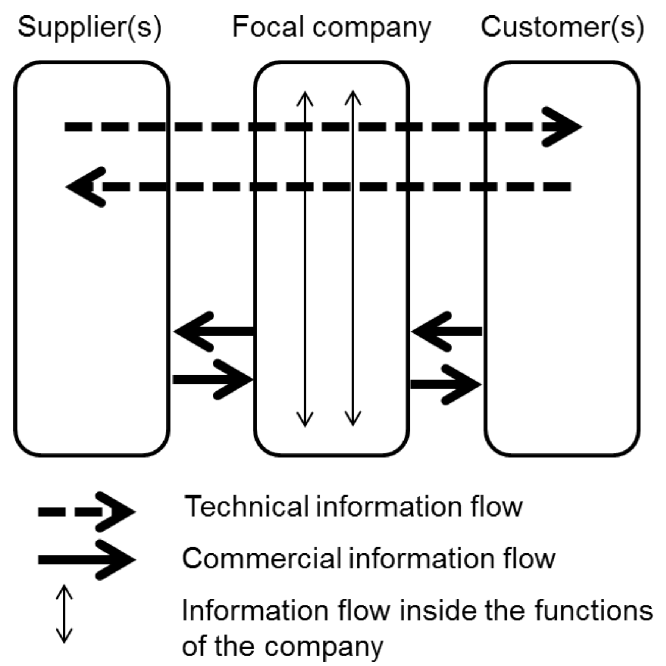

Fig. 2. The information flows between the companies involving in product developmen.

The technical information can flow from suppliers to customers and the other way round. Respectively, from the viewpoint of the focal company, the 
commercial information has to be controlled by it to avoid direct commercial collaboration among suppliers and customers. At the same time, the technical and commercial information flows go inside the different functions of the focal company in order to avoid silos between business functions.

\section{Motivating factors to joint product development efforts}

One factor motivating both purchaser and supplier companies to joint product development is naturally the success in business. Achievement of overall cost savings was a quite common answer among the interviewees of the focal company. It was also deemed important that the obtained success could be shared with suppliers in order to keep suppliers motivated.

Different actors and parties had also varying motivating factors to joint product development efforts. A purchasing manager gave an example:

"Our suppliers value product changes which make their manufacturing processes more fluent. It improves their quality and delivery performance."

Many interviewees stated that a respected subject among suppliers is the ensuring of continuity of collaboration. A joint development project can be a guarantee of continuity for both sides. However, the promise of longer collaboration can also activate suppliers to product development initiatives. This is how a purchasing manager described it:

"When we were more aggressive in bidding our suppliers they possibly felt that if they develop products together with us, we can still buy the next project from the competitors. What could then be the benefits for them of the product development with us?"

One of the interviewees (a product development director) also warned that too close relationships in product development may lead to supplier lock-ins. The interviewee continued that the desired starting point for joint product development is when it is genuinely a beneficial opportunity to both parties, both contribute with their own specific capabilities.

In the interviews, the necessity to activate and motivate suppliers to provide product development initiatives was widely stressed. Due to the complexity of products the focal company cannot have competencies on the development of all the components and technologies (a purchasing manager). According to a purchasing category manager, supplier with a good idea can radically accelerate project launches:

"We have had product development workshops together with this supplier and we have been able to reduce the manufacturing costs."
The interviewees of the focal company regarded it challenging to activate suppliers to introduce product development ideas. Many of the interviewees stated that there are only few good examples of it so far. This is how a purchasing manager described it:

"We have tried to communicate a new kind of culture to our suppliers in order to facilitate their product development ideas but it is quite difficult to obtain the ideas. [...] It is our problem to introduce appropriate rewards and we also reward our suppliers by nominations and so on. [...] We have to consider very carefully what is the motivation for suppliers to involve in product development and what the concrete benefits for the suppliers are."

Also the motivating of suppliers to involve to the product development projects of the focal company was discussed. According to a purchasing manager:

"The best way is to describe to suppliers what we are doing and why: what are the perceivable benefits, e.g. the percentual improvements in energy efficiency or production costs. Or we can communicate the expected increase in sales volumes or business areas."

According to the interviewees of the focal company, the subject that motivates suppliers to collaboration varies depending on the supplier. In a simple product manufacturing business, the main motivating factor is production volume. In contrast, some suppliers are eager to innovate and introduce new technologies regarding more complex offerings. A category manager describes the situation where supplier appreciates high technology:

"We are rather keen into development, and by that we are quite interesting customer to our suppliers. [...] Specially, when they [suppliers] want to test new products, they want to test them with us because we have highly demanding production process."

The issue of factors motivating different parties to product development was further studied in group discussions of the first workshop. Table 5 presents a summary of factors motivating the focal company, Customer, Supplier A and Supplier B to provide initiatives to product redesign process. Since the opinions of Supplier A and B merged in the joint discussion, they are presented in the same Table. The search for cost-effectiveness and overall success in business were clearly the motivating factors linking all the parties. This is how the representative of Supplier A commented it:

"The traditional means for cutting costs have already been used and that route leads to nowhere. Now we need to jointly identify means for cost savings. Small changes to products do not provide great production savings." 
Table 5

Factors motivating customers and suppliers to joint product development.

\begin{tabular}{|c|c|c|}
\hline \multicolumn{3}{|c|}{ Perspective to the research question (RQ2) } \\
\hline Supplier & Focal company & Customer \\
\hline $\begin{array}{l}\text { - Increased production volume (specifi- } \\
\text { cally in standard operations) } \\
\text { - New innovations and testing of tech- } \\
\text { nologies facilitating supplier's own prod- } \\
\text { uct development } \\
\text { - Continuity of collaboration } \\
\text { - Joint development projects bringing } \\
\text { out supplier's expertise } \\
\text { - Global presence of a customer }\end{array}$ & $\begin{array}{l}\text { Collaboration with suppliers: } \\
\text { - accelerates project launches } \\
\text { - reveals unnecessary demands in pro- } \\
\text { duct specifications } \\
\text { - reduces manufacturing costs }\end{array}$ & $\begin{array}{l}\text { - Identified challenges in manufacturing } \\
\text { - Search for cost savings in focal com- } \\
\text { pany's products } \\
\text { - Improving the appreciated features in } \\
\text { focal company's products }\end{array}$ \\
\hline \multicolumn{2}{|r|}{$\bullet$ Success in business } & \\
\hline
\end{tabular}

The representatives of Customer clearly presented that the focal company should have the active role in its own product development especially when cost savings are sought for. Too high price is communicated indirectly by Customer through a lost tendering case. Customer is primarily active when there is a certain identified problem in an existing product or its delivery which requires solutions. However, Customer was keen to utilize a better feedback system in order to deliver information regarding desired product features. The representatives of Customer suggested that lost tendering cases should be carefully analyzed in order to learn for the future biddings. Customer representatives also doubted the ability of the focal company to process the ideas given by them. They mentioned that product development engineers are often too far away from the field to which the construction has been designed.

Suppliers A and B presented that one of the main motivating factors to produce initiatives to product development is to demonstrate their own competence to the focal company. This was considered to support in assuring continuity of the relationship. Suppliers also presented that significant cost improvement potential lies in the collaborative product design. For example, a supplier can suggest alternative material changes to the components. While the suppliers regarded the development of their own products as always desirable, it was regarded that certain aspects in customer such as global and strategic status and prospective potential of business give more motivation for customer-dedicated development work. The suppliers deemed that the focal company can promote its supplier collaboration by contacting the supplier as soon as possible in the product development process and having an open conversation about product specifications. It is too late to start the discussion during the tendering phase. The collaboration in product development is the promise of business for suppliers and it was deemed to require mutual confidence between suppliers and the focal company. The openness of product cost information was valued by the suppliers but at the same time the importance of strict confidence was acknowledged.

A joint area of discussion among all the parties involved in workshop one related to the balance of relationships. There was a common agreement that if the focal company has a too dominant role in collaboration, it can in the long term economically run down a supplier. Correspondingly, if the supplier has a too dominant role in the collaboration it may not have enthusiasm for joint product development projects. The three parties ended with a collective resolution: the relationship between the supplier and the focal company is balanced when both counterparts benefit from collaboration and neither counterpart feels exploited economically.

\section{Discussion}

The findings of this study highlight specifically the importance of customer company in giving both direct and indirect signals for product development initiatives (market pull). The studied project manufacturing context requires close interaction between supplier, purchaser, and customer companies since offerings are typically tailored to customers $[19$, 21]. This is proposed as a contributing factor for the perceived importance of customer involvement in product development. Customer initiatives can have both direct (communication of preferences) and indirect (e.g. lost tendering case, price pressure) forms while supplier is typically more explicit in its initiatives. Also more formally organized collaboration practices such as supplier meetings are applied. The focal company was seemingly primarily searching for collaboration with the suppliers while the possible 
co-operation with customer was only gradually gaining more attention.

Slightly varying factors motivate different actors to join product development while the common motivators included business success and obtained cost savings. Some of the interviewees of the focal company seemed to acknowledge the need to have longer supplier relationships when closer collaboration product development was sought for, as also suggested in the earlier literature [11]. It is often meaningful to involve only carefully selected suppliers in product development [49] and apply a supply based rationalization strategy [36]. However, the focal company generally had a tendency to short supplier contracts and continuous bidding. The means for motivating suppliers were more often sought from both financial and non-financial rewarding. According to Smals and Smits [37], this kind of value for a supplier is necessary but it depends on the business network surrounding the focal purchaser-supplier dyad.

It is notable that the customer company behaved actively typically when certain deviations from desired demands both in terms of costs, product specifications or quality were identified. Hence, the results of this study reflect the study by Lagrosen [5] indicating that the main problem should be to make customers realize the value of participating in product development. Proactive contacting with lead customers is required from suppliers developing its products [41]. Suppliers, in turn, were searching for continuity and new opportunities to develop their technologies and offerings, as also suggested in the earlier literature [35]. Suppliers can obtain spin-off effects of new knowledge and competencies and expand its customer portfolio [37]. Although more active supplier collaboration was still sought for by the focal company, there appeared to already exist more established practices for supplier collaboration in comparison to customer collaboration.

Earlier studies have identified risks in involving both suppliers [2] and customer [24, 43] in product development. The representatives of the focal company did not stress the risks involved in dyadic collaboration with suppliers and customers. However, the findings of this study demonstrate the willingness of the focal company to control the direct information flows between suppliers and customer companies in order to avoid too close commercial contribution between customer companies and suppliers. Also the representatives of suppliers companies suggested that the focal company should better coordinate the collaboration between the three parties and communicate the preferences of customer companies. This suggests that one company needs to take the responsible role in coordinating the joint product development. This can also be related to the suggestion of Munksgaard et al. [50] paying attention to the focal company's need to strategize across interorganizational level in order to obtain combined and complementary strategic intentions.

\section{Conclusions}

This study contributes to the existing research by explaining the conditions facilitating joint product development between supplier, purchaser and customer companies in its initial phases. While the purchasing function intrinsically facilitates collaboration to the supplier side, it is suggested that this view should be complemented by the perspective of a customer company. Many earlier studies recognize the significance of the collaboration with suppliers in the product development process [28, 29, 51], but most existing studies do not pay any attention to the collaboration between suppliers, a focal company and customers $[27,52]$. This study also provides an interesting contextual setting for the study by emphasizing the transformation of product development in a project manufacturing company with engineeringoriented mindset. The importance of customer company in product development was raised only during the progress of this study which led to the arrangement of joint workshops between suppliers, focal company and customer company.

As a contribution to the managerial practice, this study presents how a workshop method can improve inter-organizational collaboration in product development. Joint discursive events where all the counterparts can present their improvement ideas concerning products were valued by all the actors in the workshop. The atmosphere in the workshop was open and constructive due to carefully selected and not competing parties. It appeared that especially the customer company was able to forward its message upstream. Workshops can provide a significant link between the requirements of the customer company and the capabilities of suppliers. When all the counterparts are in the same room, it is possible to discuss what components or functions are significant or insignificant in the terms of customer satisfaction.

This study has novelty value to the literature, due to its empirical access to all three different actors including supplier, purchaser and customer company. However, the study is limited to one case context which limits its external validity. The results and proposals of this study may be best applicable in similar project manufacturing environments and require more testing in the future. This study identified 
the importance of customer company perspective in product development and further study should emphasize this viewpoint more.

Authors are thankful for the financial support of the Finnish Funding Agency for Innovation and the valuable contribution by the case company representatives.

\section{References}

[1] Lin X., Germain R., Antecedents to customer involvement in product development: comparing US and Chinese firms, European Management Journal, 22, 2, 244-255, 2004.

[2] Ylimäki J, A dynamic model of supplier - customer product development collaboration strategies, Industrial Marketing Management, 43, 6, 996-1004, 2014.

[3] Lakemond N., Echtelt F., Wynstra F., A configuration typology for involving purchasing specialists in product development, Journal of Supply Chain Management, 37, 3, 11-20, 2001.

[4] Schiele H., Early supplier integration: the dual role of purchasing in new product development, R\&D Management, 40, 2, 138-153, 2010.

[5] Lagrosen S., Customer involvement in new product development: a relationship marketing perspective, European Journal of Innovation Management, 8, 4, 424-436, 2005.

[6] Brown S.L., Eisenhardt K.M., Product development: past research, present findings, and future directions, Academy of management review, 20, 2, 343378, 1995.

[7] Handfield R.B., Bechtel C., The role of trust and relationship structure in improving supply chain responsiveness, Industrial Marketing Management, 31, 4, 367-382, 2002.

[8] Ragatz G.L., Handfield R.B., Scannell T.V., Success factors for integrating suppliers into new product development, Journal of Product Innovation Management, 14, 3, 190-202, 1997.

[9] Yeniyurt S., Henke Jr J.W., Yalcinkaya G., A longitudinal analysis of supplier involvement in buyers' new product development: working relations, interdependence, co-innovation, and performance outcomes, Journal of the Academy of Marketing Science, 42, 3, 291-308, 2014.

[10] Gruner K.E., Homburg C., Does customer interaction enhance new product success?, Journal of Business Research, 49, 1, 1-14, 2000.

[11] Svendsen M.F., Haugland S.A., Grønhaug K., Hammervoll T., Marketing strategy and customer in- volvement in product development, European Journal of Marketing, 45, 4, 513-530, 2011.

[12] Kaulio M.A., Customer, consumer and user involvement in product development: a framework and a review of selected methods, Total Quality Management, 9, 1, 141-149, 1998.

[13] Imeri S., Shahzad K., Takala J., Liu Y., Sillanpää I., Ali T., Evaluation and selection process of suppliers through analytical framework: an emprical evidence of evaluation tool, Management and Production Engineering Review, 6, 3, 10-20, 2015.

[14] Ritter T., Walter A., Relationship-specific antecedents of customer involvement in new product development, International Journal of Technology Management, 26, 5-6, 482-501, 2003.

[15] Stump R.L., Athaide G.A., Joshi A.W., Managing seller-buyer new product development relationships for customized products: a contingency model based on transaction cost analysis and empirical test, Journal of Product Innovation Management, 19, 6, 439-454, 2002.

[16] Chien S.H., Chen J.J., Supplier involvement and customer involvement effect on new product development success in the financial service industry, The Service Industries Journal, 30, 2, 185-201, 2010.

[17] Brockhoff K., Customers' perspectives of involvement in new product development, International Journal of Technology Management, 26, 5-6, 464481, 2003.

[18] Gosling J., Naim M.M., Engineer-to-order supply chain management: a literature review and research agenda, International Journal of Production Economics, 122, 2, 741-754, 2009.

[19] Gunasekaran A., Ngai E.W., Build-to-order supply chain management: a literature review and framework for development, Journal of Operations Management, 23, 5, 423-451, 2005.

[20] González-Benito J., Effect of the characteristics of the purchased products in JIT purchasing implementation, International Journal of Operations and Production Management, 22, 8, 868-886, 2002.

[21] Eriksson P.E., Improving construction supply chain collaboration and performance: a lean construction pilot project, Supply Chain Management: An International Journal, 15, 5, 394-403, 2010.

[22] Ahola T., Laitinen E., Kujala J., Wikström K., Purchasing strategies and value creation in industrial turnkey projects, International Journal of Project Management, 26, 1, 87-94, 2008.

[23] Eriksson P.E., Westerberg M., Effects of cooperative procurement procedures on construction project 
performance: a conceptual framework, International Journal of Project Management, 29, 2, 197-208, 2011.

[24] Tollin K., Customization as a business strategy a barrier to customer integration in product development?, Total Quality Management, 13, 4, 427-439, 2002.

[25] Luzzini D., Amann M., Caniato F., Essig M., Ronchi S., The path of innovation: purchasing and supplier involvement into new product development, Industrial Marketing Management, 47, 109-120, 2015.

[26] Azadegan A., Dooley K.J., Supplier innovativeness, organizational learning styles and manufacturer performance: An empirical assessment, Journal of Operations Management, 28, 6, 488-505, 2010.

[27] Lau A.K., Supplier and customer involvement on new product performance: contextual factors and an empirical test from manufacturer perspective, Industrial Management and Data Systems, 111, 6, 910942, 2011.

[28] Song M., Di Benedetto C.A., Supplier's involvement and success of radical new product development in new ventures, Journal of Operations Management, 26, 1, 1-22, 2008.

[29] Wynstra F., Van Weele A., Weggemann M., Managing supplier involvement in product development: three critical issues, European Management Journal, 19, 2, 157-167, 2001.

[30] Wagner S.M., Hoegl M., Involving suppliers in product development: insights from RED directors and project managers, Industrial Marketing Management, 35, 8, 936-943, 2006.

[31] Schiele H., Accessing supplier innovation by being their preferred customer, Research-Technology Management, 55, 1, 44-50, 2012.

[32] Melander L., Rosell D., Lakemond N., In pursuit of control: involving suppliers of critical technologies in new product development, Supply Chain Management: An International Journal, 19, 5/6, 722-732, 2014.

[33] Rowley T., Behrens D., Krackhardt D., Redundant governance structures: an analysis of structural and relational embeddedness in the steel and semiconductor industries, Strategic Management Journal, $21,3,369-386,2000$.

[34] Ellis S.C., Henke J.W., Kull T.J., The effect of buyer behaviors on preferred customer status and access to supplier technological innovation: an empirical study of supplier perceptions, Industrial Marketing Management, 41, 8, 1259-1269, 2012.

[35] Wagner S.M., Bode C., Supplier relationship-specific investments and the role of safeguards for supplier innovation sharing, Journal of Operations Management, 32, 3, 65-78, 2014.

[36] Koufteros X.A., Cheng T.E., Lai K.H., "Black-box" and "gray-box" supplier integration in product development: antecedents, consequences and the moderating role of firm size, Journal of Operations Management, 25, 4, 847-870, 2007.

[37] Smals R.G., Smits A.A., Value for value - the dynamics of supplier value in collaborative new product development, Industrial Marketing Management, 41, 1, 156-165, 2012.

[38] Lakemond N., Berggren C., Weele A., Coordinating supplier involvement in product development projects: a differentiated coordination typology, R\&D Management, 36, 1, 55-66, 2006.

[39] Petersen K.J., Handfield R.B., Ragatz G.L., Supplier integration into new product development: coordinating product, process and supply chain design, Journal of Operations Management, 23, 3, 371-388, 2005.

[40] Larsson B., Sundqvist J., Emmitt S., Component manufacturers' perceptions of managing innovation, Building Research and Information, 34, 6, 552-564, 2006 .

[41] Greer C.R., Lei D., Collaborative innovation with customers: A review of the literature and suggestions for future research, International Journal of Management Reviews, 14, 1, 63-84, 2012.

[42] Lichtenthaler U., Open innovation in practice: an analysis of strategic approaches to technology transactions, IEEE Transactions on Engineering Management, 55, 1, 148-157, 2008.

[43] Nambisan S., Designing virtual customer environments for new product development: toward a theory, Academy of Management Review, 27, 3, 392413, 2002.

[44] Yin R.K., Case Study Research - Design and Methods, Thousand Oaks, California: Sage Publications, 2009 .

[45] Eppinger S.D., Whitney D.E., Smith R.P., Gebala D.A., A model-based method for organizing tasks in product development, Research in Engineering Design, 6, 1, 1-13, 1994.

[46] Flick U., An Introduction to Qualitative Research, London: Sage Publications, 2002.

[47] Van De Ven A., Delbecq A.L., Nominal versus interacting group processes for committee decisionmaking effectiveness, Academy of Management Journal, 14, 2, 203-212, 1971.

[48] Kim S.H., Ahn B.S., Interactive group decision making procedure under incomplete information, Euro- 
pean Journal of Operational Research, 116, 3, 498507, 1999.

[49] McElroy J., The development partner, World Class Design to Manufacture, 2, 5, 5-10, 1995.

[50] Munksgaard K.B., Clarke A.H., Storvang P., Erichsen P.G., Product development with multiple partners: strategies and conflicts in networks, Industrial Marketing Management, 41, 3, 438-447, 2012.
[51] Dubois A., Wynstra F., Organising the purchasing function as an interface between internal and external networks, Proceedings of the 21st Annual IMP Conference, Rotterdam, September 1st-3th, 2005.

[52] Lawson B., Petersen K.J., Cousins P.D., Handfield R.B., Knowledge sharing in interorganizational product development teams: the effect of formal and informal socialization mechanisms, Journal of Product Innovation Management, 26, 2, 156-172, 2009. 